\title{
Introduction: Gendered Education in History, Theory and Practice
}

\author{
Carl Antonius Lemke Duque \\ University of Navarra \& \\ University of Deusto
}

\section{Álvaro Chaparro Sáinz} University of Malaga

Although Education Science in its broad sense and the History of Education in its more specific limitations have not paid much attention to the social and political theory of Jürgen Habermas, there is no doubt that his critical analysis of secularized modernity and deliberative democracy provides a series of insights that allow one to deepen and better understand the current problems of education systems and their historical institutions in Western societies. Habermas shares with pedagogues like John Dewey and others, a critical defense of the historical project of the Enlightenment, above all, centered on the key issues of the autonomy (Autonomie) and responsibility (Mündigkeit) of the individual. Both in Dewey and in Habermas we can find an offensive identification of the practice of democracy with the conditions of so-called communicative actions. Both thinkers aspire to recover the value of the individual against an unrestrained and omnipresent capitalist ethos. The main reference of the search for a new normative framework for democratic societies focuses, primarily, on an intersubjective dimension that is considered as the core of non-sovereign communicative actions and, hence, as a decisive source for the liberty of the individual facing the power structures of the modern world. In a similar way, Hannah Arendt had raised the reflective judgment (reflektierende Urteilskraft), fed from the aesthetics of Immanuel Kant, as the main way of passing the idea of philosophical freedom towards social dimensions, that is, to turn it into political freedom: both in Arndt and in Habermas, this transformation is only possible within a sphere of human plurality (cf. Thaa, 2005).

Habermas has developed his theory of communicative action in direct relation to the question of the historical background and the modern disintegration of the public sphere, conceived as a free space for the rational-discursive formation of a critical consciousness of the political. It is known, however, that his analysis of the public as a paradigmatic source for the normative framework of rational society led to a narrative a la Max Weber-tinged with pessimism following the Frankfurt School-about the loss of individual liberties due to the effects of a predominant process of technocratic bureaucratization. From this perspective, the impenetrable rigidity of the bureaucratic system is part of a long and persistent evolvement of modern rationalization in Western societies that, finally, starts even to invade the public sphere annihilating the formal presupposition of its historical emergence as bourgeois public: the separation between the public and the private. Successively, more and more areas of society are being subjected to the bureaucratic mechanics of the State, extending the process of modern rationalization not only to the policy itself but also to the field of education, in particular (cf. Held, 1980, pp. 260-267).

It is true that Habermas' critique of the modern degeneration of the public and his efforts

Date of submission: 2018-11-06

Date of acceptance: 2018-11-26

ISSN 2560-8371

http://doi.dx.org/ 10.24908/eoe-ese-rse.v19i0.12837

(c) Encounters in Theory and History of Education 1 
on a broad theory of communicative action did have some, even very limited impact on Educational Science, especially in the early 1990s. This pedagogical reception of Habermas' theory of communicative action has focused less on its general constitutive dimension as an ethical-transcendental source for a new normativity of rational society, but mainly on the momentum of the emancipation of the individual. The American sociologist Jack Mezirov, particularly, has integrated Habermas' discursive ethics systematically into his model of transformative learning (cf. Kitchenham, 2008). At the same time, the idea and characteristics of the public in Habermas have been openly criticized for its exclusively liberal-bourgeois approach. Although affirming the general setting of his critique, Nancy Fraser for instance has reproached Habermas for his unilateral vision of the public sphere as being particularly blind with respect to the various feminine spaces growingly present as a research topic not only for the $19^{\text {th }}$ Century but to Early Modern History as well (see Becker, 2017). From a broader perspective of recent feminist critique, the Habermasian idealization of one single public sphere has been confronted with alternative models defending the idea of the public constituted by multiple spheres (cf. Wain, 2004, pp. 135-177).

Another critical horizon to both the Education Sciences in general and the more specific field of the History of Education, refers to Michel Foucault's genealogy of power that has been considered, again in recent years, as an important sociological background for updating both pedagogical theory and practice. Analyzing the concrete materiality of language and its functionalization as discursive ideology, Foucault has proposed in the context of his latter works the concept of gouvernementalité as a complex of activities, methods and techniques that provides the possibilities of shaping a governable human subject by means of its multidimensional matrix. Beyond its initial and rather mechanical approach to discursive power as hidden structures and relations, this idea of sociopolitical preconditions refers both to an increasing governance of any social order by the State and to a substantially augmented internalization of norms and directives regulating subjective behavior of the individual. The core of the concept of gouvernementalité lays in the fact that, through this multidimensional matrix, liberty becomes a decisive resource for governability, that is, for the political rationality of society itself (cf. Doberty, 2007).

This novel extrapolation from the latter stage of critical discursive analysis in Foucault corresponds with two different approaches of understanding a Foucaultian mode of research in both Education Sciences and the History of Education in particular. One can focus, on the one hand, on the question of identifying and analyzing the rules of the formation of discoursescalled historical a priori that constitute a broader field of episteme according to the genealogy of power-in the sense of something positively operating both in the same pedagogical investigation as in the topics and problems that are being investigated. Against this archaeological approach of dismantling the different regimes of truth, the late Foucaultian mode, on the other hand, extends its focus to the question of the human subject and its self-constitution in modern society. From this nuanced perspective, the structuralist analytics of power as a previously given order of truth, is being transformed into a continuous search for cultural, social, political conditions, etc. conceived as games of truth. Here, the ethic of self-constitution of the human subjects entering strategically in the multiple simulations of possible truth is what constitutes the key challenge for pedagogical research (cf. Peters, 2007).

Both, the feminist critique of a multiple concept of the public according to Habermas as 
well as the discursive analysis of the hidden mechanisms of power and of the fragile systemic conditions of political freedom in Foucault can be considered as two central columns for rethinking the rise and progress of the modern learning society. In the field of the history of education, the issue of gender has become, during the last two decades especially, a factor increasingly present in the studies of the historical processes of economic and socio-political modernization as of the ideas and theories of pedagogical innovation. Within this growing trend, research has focused, from a comparative perspective as well, on socio-cultural and politicalinstitutional contexts of education systems for girls and women in various countries in Europe and North America, since the Enlightenment in particular (see recently, Panayotidis \& Stortz, 2016; Walgenbach \& Stach, 2015). In this context, though, religious teaching and socialization (mostly Catholic and Protestant) provided through the education systems of Western societies, are still investigated primarily within the restricted perspectives of national frameworks (see for instance, Mattingly, 2016; Krause, 2010, Edelbrock, 2006, etc.).

From a historiographical view, less attention has been paid so far to the question of content analysis, particularly of feminist debates on education (see Strauss Sotiropoulos, 2007) and transnational issues and cultural transfers (see Raftery \& Clarke, 2017). Something similar about its relationship with the issue of gender occurs not only with the issues of violence and sexuality, actually representing two core aspects of modern pedagogy and educational systems (see Mahs, 2016), but also with studies on the alterations of masculinity within different spaces of education (see Brownhill, 2016; Bowl, 2012). Another gap in the research refers to the systematic dimension that gender theory provides to the question for pedagogical interconnection between theory and praxis, taking into account the idealist impact of educational systems on the social and professional behavior of women and men in modern societies (see Micus-Loos, 2016; Gill, 2016). A crucial factor for the question of the ethical self-constitution of the subject and the normative dimension of the public sphere from the perspective of Education Science and the History of Education refers to the topic of both historical and current processes of migration and their relationship with the issue of gender (see Hoyer, 2015; Diehm \& Messerschmidt, 2013). One might argue in this context, that any plural society understood as a profound experience of differences, requires a broad practice of social and political integration, becoming thereby a key aspect for pedagogical research in general. The great potential of this question in order to stimulate the further development of modern learning societies is reflected in recent contributions focusing on diversity competences (see Pohl \& Siebenpfeiffer, 2016; Dietz, 2009).

In order to offer a broad approach to these gender-related aspects that allow one to rethink the rise and progress of the modern learning society, the present special issue has put together seven diverse studies that share as a unifying element the focus on the processes of gendered diversification in Education Sciences. Since theses seven studies range from Sociology to Pedagogy, going through Modern and Contemporary History, they cover divergent approaches and controversies from the eighteenth century to the twenty-first century deepening into three specific national cases (France, Turkey, Spain) as well as into postmodern conceptual analysis including pedagogical practice. These seven studies compiled in this issue are presented in the following three subsections: In the first place, (1) an "Education Policy and Gendered Education in Longue Durée Perspective" allows us to widen the angle of critical perspective. In his contribution, Ansgar Weymann (University of Bremen) analyzes, from a sociological perspective, 
the historical limits and possibilities of educational policies, understanding them as political and economic tools of the modern State, taking into account a gender aspect by focusing on the notable changes that have taken place in the last decades relating to women's education.

The second section (2) on "Past and Present of Women's Education in Europe" embraces three studies contrasting the progressive extension of secularized education in France between the eighteenth and nineteenth century with the process of de-secularization of education in current Turkey. Firstly, Dominique Picco (University of Bordeaux-Montaigne) studies the education of female descendants of French noble families at the center of education Maison Royale de Saint-Louis in Saint-Cyr during the $18^{\text {th }}$ century. The author delves into the pedagogical principles of this famous educational institution by analyzing Madame de Maintenon's work and contextualizing this institution in relation to other centers of education of this period. Stepping forward in time, Rebecca Rogers (University of Paris Descartes, Sorbonne) explains the transformations in the French school system at the end of the $19^{\text {th }}$ century from a gendered perspective. The author offers an analysis of the systematization and segmentation of European school systems between 1870 and 1920, showing the importance of female teachers in the changes that have taken place in the educational system, not only in France but in the colonies as well, as a consequence of women's initiatives. Thirdly, Ayşe Durakbaşa and Funda Karapehlivan Şenel (University of Marmara, Istanbul - retired) focus on the process of islamization of the Turkish education system in recent years, deepening into the consequences this process is causing in female education. This study focuses especially on the so-called Imam Hatip Schools where Islamic teaching is gaining terrain in parallel with the conventional curriculum.

Finally, the third section (3) on "Gendered Spaces and the Performativity of Knowledge," compiles studies with a theoretical and practical approach. This block is assigned to the analysis of social dynamics that determine educational spaces, public or private, institutional, discursive or virtual; at the same time, this section offers an approach to the impact of a postmodern conception of knowledge in relation to the theory of gender for pedagogy and educational systems. From a casuistic level of oral historiography, Aurora Morcillo (Florida International University, Miami) focuses on the repression of the student movement that took place at the University of Granada (Spain) during the state of emergency in 1970. In her analysis, the author explores, through two testimonies, how the students transgressed the official discourse on the Catholic ideal of women, claiming for a neutral gender-related space for achieving both academic responsibilities as well as democratic and feminist freedom. Focusing on postmodern concepts of education, Kerstin Jergus (University of Fribourg) delves into the conditions in which identity is created within the framework of gender politics. In her work, the author asks about how a critical and sustainable gender discourse can be shaped in academic spaces. According to the final study of this special issue by Thorsten Knauth (University of Duisburg-Essen), current Religious Education is progressively transforming gender aspects into a more comprehensive category of difference shaped through diversified social, religious and cultural backgrounds related to specific dis/ability. His article explains how to understand boyhood from the perspective of gender-related diversity.

\section{References}

Becker, A. (2017). Gender in the History of Early Modern Political Thought. The Historical Journal, 60 (4), 
843-863.

Bowl, M. \& et al. (Eds.) (2012). Gender, masculinities and lifelong learning. London: Routledge.

Simon Brownhill et al. (Eds.) (2016). Men, masculinities and teaching in early childhood education. International perspectives on gender and care. London: Routledge.

Diehm, I \& Messerschmidt, A. (Eds.) (2013). Das Geschlecht der Migration. Bildungsprozesse in Ungleichheitsverhältnissen. Opladen: Verlag Barbara Budrich.

Dietz, G. (2009). Multiculturalism, Interculturality and Diversity in Education. Anthropological Approach. Münster/New York: Waxmann.

Doberty, R. (2007). Critically Faming Educational Policy: Foucault, Discourses and Governmentality. In M. Peters \& T. Besley (Eds.), Why Foucault? New directions in educational research (pp. 193-204). New York: Lang.

Edelbrock, A. (2006). Mädchenbildung und Religion in Kaiserreich und Weimarer Republik. Eine Untersuchung zum evangelischen Religionsunterricht und zur Vereinsarbeit der Religionslehrerinnen. Neukirchen-Vluyn: Neukirchener Verl.

Gill, J. \& et al. (2016). A girl's education. Schooling and the formation of gender, identities and future visions. Palgrave Macmillan.

Held, D. (1980). Introduction to Critical Theory. Horkheimer to Habermas. London: Hutchinson.

Hoyer, B. (Ed.) (2015). Migration und Gender. Bildungschancen durch Diversity-Kompetenz. Opladen: Budrich UniPress.

Kitchenham, A. (2008). The Evolution of John Mezirow's Transformative Learning Theory. Journal of Transformative Education, 6, 104-123.

Krause, S. (2010). "Marienkinder" im Katholizismus des 19. Jahrhunderts. Religiosität, Weiblichkeit und katholische Gesellschaftsbildung. Berlin: Frank \& Timme.

Mahs, C. \& et al. (Eds.) (2016). Erziehung, Gewalt, Sexualität. Zum Verhältnis von Geschlecht und Gewalt in Erziehung und Bildung. Opladen: Verlag Barbara Budrich.

Mattingly, C. (2016). Secret habits. Catholic literacy education for women in the early nineteenth century. Carbondale: Southern Illinois University Press.

Micus-Loos, C. \& et. al. (Eds.) (2016). Normative Orientierungen in Berufs- und Lebensentwürfen junger Frauen. Wiesbaden: Springer.

Peters, M. A. (2007). Educational Research: 'Games of Truth' and the Ethics of Subjectivity. In M. Peters \& T. Besley (Eds.), Why Foucault? New directions in educational research (pp. 181-191). New York: Lang.

Panayotidis, E. L. \& Paul Stortz, P. (Eds.) (2016). Women in higher education (1850-1970). International perspectives. New York: Routledge.

Pohl, P. C. \& Siebenpfeiffer, H. (Eds.) (2016). Diversity trouble. Vielfalt - Gender-Gegenwartskultur. Berlin: Kulturverlag Kadmos.

Raftery, D. \& Clarke, M. (Eds.) (2017). Transnationalism, gender and the history of education. London: Routledge.

Strauss Sotiropoulos, C. (2007). Early feminists and the education debates. England, France, Germany (1760-1810). Madison, WI: Fairleigh Dickinson Univ. Press.

Thaa, W. (2005). Kulturkritik und Demokratie bei Max Weber und Hannah Arendt. Zeitschrift für Politik, 52 (1), 25-56.

Wain, K. (2004). The learning society in a postmodern world. The education crisis. New York: Peter Lang.

Walgenbach, K. \& Stach, A. (Eds.) (2015). Geschlecht in gesellschaftlichen Transformationsprozessen. Opladen: Verlag Barbara Budrich. 